\title{
Micropropagation of Agapanthus umbellatus var. minor by using two systems of multiplication
}

\section{Micropropagação de Agapanthus umbellatus var. minor com dois sistemas de multiplicação}

\author{
Luciana Alves Fogaça ${ }^{1 *}$; Enio Luiz Pedrotti²; Antonio Carlos Alves ${ }^{2}$
}

\begin{abstract}
For conventional micropropagation methods, semisolidified medium (SM) is used; the use of this medium requires intense manipulation of the cultures and skilled labor. Systems that use liquid medium show equal or better efficiency of the multiplication process, besides reducing the cost for the elimination of agar. In this study, we evaluated the mass propagation of Agapanthus umbellatus var. minor two in vitro multiplication systems (SM system and temporary immersion system [SIT]). The plant material was grown in MS medium supplemented with 6-benzylaminopurine (6-BA; 0.0, 8.9, 17.8, and 35.6 $\mu \mathrm{M})$. The data obtained in this study demonstrate that the two systems used were efficient for the multiplication phase of this species. However, we recommend SIT in view of its reuse in the process of multiplication and rooting. Moreover, simple construction, low cost of the culture medium, and low cost of the bioreactors and the fact that agar is not required qualify this system as an efficient alternative for large-scale micropropagation of Agapanthus umbellatus var. minor. We recommend 17.8 $\mu \mathrm{M}$ 6-BA for the SM system and $8.9 \mu \mathrm{M}$ 6-BA for SIT.
\end{abstract}

Key words: In vitro culture. Temporary immersion. Semisolidified medium. Cytokine.

\section{Resumo}

Na metodologia convencional de micropropagação utiliza-se meio nutritivo geleificado, o que acarreta intensa manipulação das culturas e envolve mão-de-obra especializada. Porém, há uma tendência em se utilizar biorreatores em meio líquido com igual ou até melhor eficiência do processo de multiplicação, além de diminuir o custo pela eliminação do ágar. O presente trabalho teve como objetivo comparar a eficiência do uso do meio geleificado (MG) e de biorreator de imersão temporária (BIT), visando a propagação em massa de Agapanthus umbellatus var. minor. O material vegetal cresceu em meio MS suplementado com diferentes concentrações de 6-BAP $(0,0 ; 8,9 ; 17,8$ e 35,6 $\mu \mathrm{M})$. As avaliações de crescimento e desenvolvimento aos 60 dias mostraram que ambos os sistemas foram eficientes na fase de multiplicação. No entanto, a imersão temporária pode ser recomendada, com vista à sua reutilização no processo de multiplicação e enraizamento. Além disso, sugere-se este sistema como uma alternativa eficiente para a micropropagação em larga escala desta espécie por sua simplicidade na construção, custo mais baixo do meio de cultura, por não utilizar ágar e pelo baixo custo dos biorreatores. Dentre as concentrações utilizadas nos sistemas, recomenda-se a concentração de 17,8 $\mu \mathrm{M}$ de 6-BAP para o MG e $8,9 \mu \mathrm{M}$ de 6-BAP para o BIT.

Palavras-chave: Cultura in vitro. Imersão temporária. Meio geleificado. Citocinina.

\footnotetext{
1 Prof $^{a}$ Dra $^{\mathrm{a}}$, Curso de Agronomia, Pontifícia Universidade Católica do Paraná, PUC-PR, Escola de Ciências da Vida, Campus Toledo, Toledo, PR, Brasil. E-mail: luciana.f@pucpr.br

2 Profs. Drs., Curso de Agronomia, Universidade Federal de Santa Catarina, UFSC, Centro de Ciências Agrárias, Florianópolis, SC, Brasil. E-mail: pedrotti@cca.ufsc.br; alves@cca.ufsc.br

* Author for correspondence
} 


\section{Introduction}

Agapanthus umbellatus var. minor is commonly known as the lily of the Nile. It is an angiosperm from the family Agapanthaceae (SNOEIJER, 2004), and it is an ornamental plant commonly used as cut flowers because of its durability. However, the considerable economic interest in this species is attributable to its use in landscapes and parks (LORENZI, 2015).

Agapanthus propagation is traditionally performed by dividing clumps. However, this technique has many disadvantages, such as low propagation tax and the fact that one plant produces only ten seedlings per year. Furthermore, there is the possibility of pest and disease dispersion in new fields of production. Therefore, micropropagation could be a very promising method for this species.

Few studies on seedling production in Agapanthus umbellatus var. minor have been performed. Exterckoker and Pedrotti (2001) obtained positive results by using the conventional system of direct organogenesis from flower buds. Fogaça et al. (2007) studied the morphological and physiological traits of Agapanthus umbellatus var. minor shoots multiplied in vitro. Suzuki et al. (2002) and Wang et al. (2012) obtained seedlings of Agapanthus praecox ssp. orientalis from embryogenic callus. Recently, Baskaran and Staden (2013) performed plant regeneration via an in vitro micropropagation system from shoot-tip cultures of Agapanthus praecox Wild.

Semisolidified medium (SM) is used for conventional propagation techniques of cloning. However, cloning involves periodic transferences of plant material to fresh medium, after subculture of four to six weeks. Currently, there is a tendency to use liquid medium in a temporary immersion system (SIT) for the fast growth of explants (LORENZO et al., 1998; ETIENNE; BERTHOULY, 2002; RODRIGUES et al., 2006; SILVA et al., 2007; NASCIMENTO et al., 2012).

According to Teisson and Alvard (1994), SIT is based on the principle that the shoots grow faster and better in liquid medium, followed by drainage of the medium at pre-established intervals. Greater contact with the shoot culture medium significantly increases nutrient absorption, since the nutrients can be absorbed by the leaves, stems, and roots (GEORGE, 1996). Furthermore, SIT combines aeration of the tissues, promoting renewal of the atmosphere in culture flasks. These features were usually not combined in classic studies performed in vitro, where the liquid remained stagnant at the bottom of the bottle (ALVARD et al., 1993).

For micropropagation to become economically viable, it is necessary to examine some factors associated with the growth and development pattern of explants, such as the composition of the culture medium in relation to the concentrations of nutrients, vitamins, carbon source, and exogenous growth regulators (CALDAS et al., 1998; VILLA et al., 2014). Among the numerous growth regulators, the cytokinin 6-benzylaminopurine (6-BA) has been efficient for shoot proliferation in many species and is commonly used (GEORGE, 1996).

In this study, we aimed to compare the efficiency of micropropagation of Agapanthus umbellatus var. minor during multiplication by using SM, SIT, and concentrations of 6-BA.

\section{Material and Methods}

\section{Multiplication}

This study was performed at the Laboratory of Morphogenesis and Vegetal Biochemistry, Center of Agrarian Sciences of Universidade Federal de Santa Catarina, Florianópolis, Santa Catarina State, Brazil.

For the systems of multiplication, SM and SIT were evaluated. The explants used were obtained by direct organogenesis of floral buds, according to a protocol described by Exterckoker and Pedrotti (2001). Plantlets were maintained in SM MS + 17.8 $\mu \mathrm{M}$ 6-BA. Before inoculation in the two systems, 
plantlets obtained from the third subculture were individualized and standardized, with heights ranging from 2.5 to $3 \mathrm{~cm}$ and three leaves.

The experimental design was completely randomized. We tested the two multiplication systems (SM and SIT) and four concentrations of 6-BA $(0.0,8.9,17.8$, and $35.6 \mu \mathrm{M})$ : a total of eight treatments and a $2 \times 4$ factorial design. The $\mathrm{pH}$ of all media was adjusted to 5.9 before autoclaving at 121 ${ }^{\circ} \mathrm{C}$ and $1.2 \mathrm{~kg} \cdot \mathrm{cm}^{2}$ pressure for $15 \mathrm{~min}$.

The SM system explants were transferred to 300-ml flasks containing $50 \mathrm{ml}$ of SM MS medium (MURASHIGE; SKOOG, 1962) containing 6 $\mathrm{g} \cdot \mathrm{L}^{-1}$ of agar (Vetec, Rio de Janeiro, Brazil). Each treatment was replicated thrice: 10 flasks with five explants each, and a total of 50 plants per replication. The flasks of the two systems were maintained in a growth room at $22 \pm 2{ }^{\circ} \mathrm{C}$ and 16 -h photoperiod (215 $\left.\mu \mathrm{mol} \cdot \mathrm{m}^{-2} \cdot \mathrm{s}^{-1}\right)$ under cool white fluorescent lamps (PHILIPS - TLT 40W, Sao Paulo, Brazil) for a period of 60 days.

For the SIT system, the explants were transferred to flasks containing $500 \mathrm{ml}$ of liquid MS medium (MURASHIGE; SKOOG, 1962). Each treatment had three flasks (replications) containing 50 plants each. The flasks and the medium were autoclaved separately: $30 \mathrm{~min}$ for the flasks and $15 \mathrm{~min}$ for the liquid medium at $121^{\circ} \mathrm{C}$ and $1.2 \mathrm{~kg} \cdot \mathrm{cm}^{2}$ pressure.

The morphological parameters of the explants obtained of the two systems were evaluated, such as number and height $(\mathrm{cm})$ of shoots, number and length $(\mathrm{cm})$ of roots, number of leaves, fresh and dry mass $(\mathrm{mg})$ of shoots and roots were quantified after 60 days.

The shoot height and root length were determined using a graduated scale $(\mathrm{mm})$. The fresh and dry mass $(\mathrm{g})$ values of the shoots were determined using 25 seedlings per replicate that were selected randomly. After washing the seedlings, the roots were separated from the shoots and placed on a paper to dry and then weighed on a precision balance (KERN, 430-21; precision, 0.0001 g; Balingen-Frommern, Germany). Then, the shoots were wrapped in paper bags and maintained in an incubator (SP-100/A; São Paulo, Brazil) at $60{ }^{\circ} \mathrm{C}$ for $24 \mathrm{~h}$. After this period, the material was weighed using the precision balance to determine the dry mass.

\section{Statistical analysis}

Statistical significance was determined using one-way analysis of variance (ANOVA) with SANEST (ZONTA; MACHADO, 1984). When significant effects were detected between treatments, comparison of mean values was performed using Duncan's test at a 0.05 level of probability. The values obtained for the number of shoots, roots, and leaves were transformed into $\sqrt{ } \mathrm{x}+1$.

\section{SIT}

The bioreactor was handmade at the Laboratory of Morphogenesis and Vegetal Biochemistry (LMBV/CCA/UFSC), and it consists of two compartments: an upper one with a capacity of 3 1 , which contained the explants, and a lower one with a capacity of 11 , which contained $500 \mathrm{ml}$ of nutrient solution (Figure 1). The two compartments are connected by a silicone tube. Each compartment has an opening: the one for the lower compartment is for the entry of compressed air and that for the upper compartment is for the vent. These holes are filled with silicone hoses with Millipore filters (0.2-mm pore; Millex - FG50, France) to avoid contamination; the bioreactor is similar to the $\mathrm{BIT}^{\circledR}$ twin flasks system used by Escalona et al. (1999). 
Figure 1. (A) Diagram of the temporary immersion system (SIT) built at the Laboratory of Morphogenesis and Vegetal Biochemistry/CCA/UFSC. (B) A bottle containing Agapanthus seedlings.

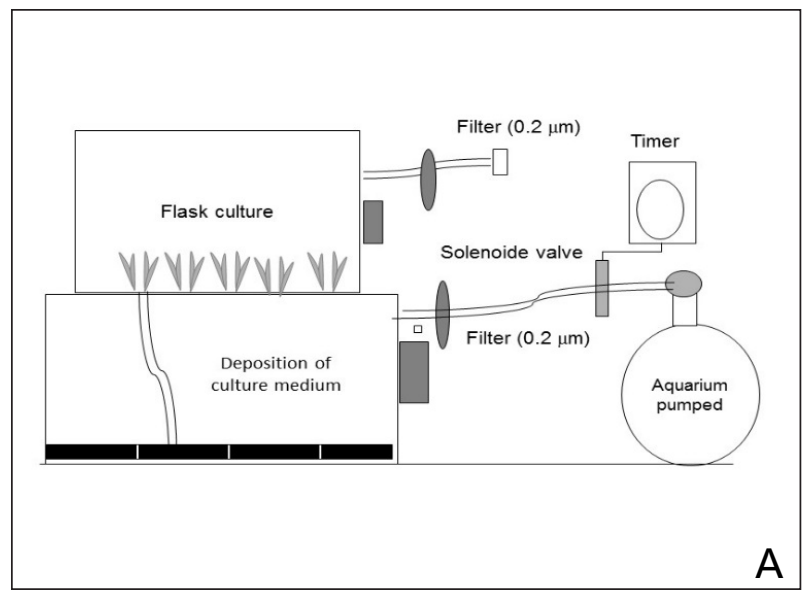

The nutrient solution remained in the lower compartment. Every 2 h, when light was provided in the growth room, the liquid medium was pumped into the upper compartment for 1 min (SILVA et al., 2007). An aquarium pump (Nevoni, São Paulo, Brazil) and a timer switch (Gubintec TI-12A, Manaus, Brazil) that controlled the frequency and duration of the immersion stage were used. After the transfer of the medium to the upper compartment, the excess air promoted the aeration of the medium in contact with the explants. After $1 \mathrm{~min}$, the air pressure in the lower ended and the medium was sent back by gravity, remaining there until the cycle repeats.

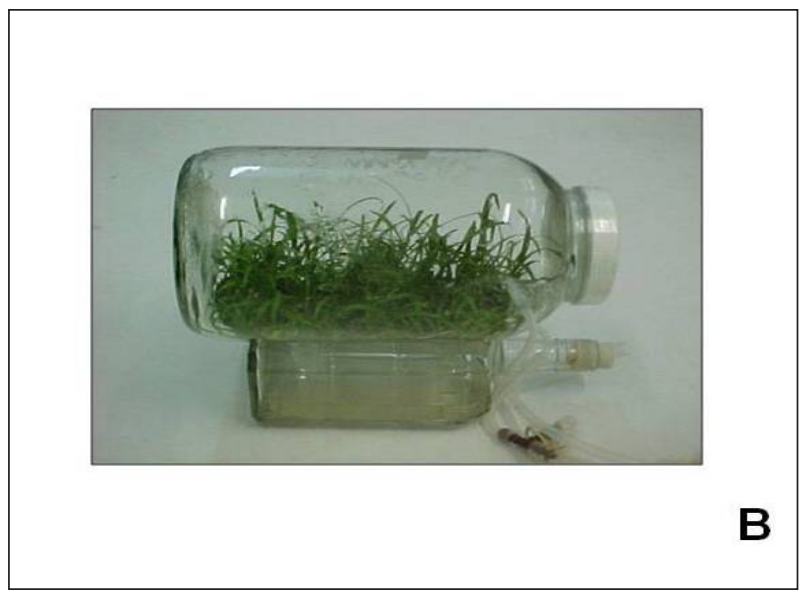

\section{Results and Discussion}

The number of shoots per explant obtained using the two systems of multiplication and four 6-BA concentrations is listed in Table 1. An interaction was observed between 6-BA concentrations and the systems of multiplication for this variable. Maximum shoots were obtained using the SM system containing $17.8 \mu \mathrm{M}$ 6-BA (5.2 shoots per explant) and SIT containing 35.6 $\mu \mathrm{M}$ 6-BA (4.6 shoots per explant) (Table 1). However, the number of shoots obtained at $8.9 \mu \mathrm{M}$ 6-BA from SIT did not differ significantly from that obtained at $35.6 \mu \mathrm{M}$ 6-BA (Table 1).

Table 1. Number of shoots per explant of Agapanthus umbellatus var. minor obtained after 60 days of culture in the semisolidified medium, temporary immersion, and four concentrations of 6-BA.

\begin{tabular}{ccc}
\hline & \multicolumn{2}{c}{ Multiplication system } \\
\cline { 2 - 3 } 6-BA & Semisolidified medium $^{1}$ & Temporary immersion $^{1}$ \\
\hline concentration $(\mu \mathrm{M})$ & $2.84 \mathrm{cA}$ & $3.41 \mathrm{bA}$ \\
8.9 & $3.80 \mathrm{bA}$ & $4.01 \mathrm{abA}$ \\
17.8 & $5.24 \mathrm{aA}$ & $3.67 \mathrm{bB}$ \\
35.6 & $3.97 \mathrm{bA}$ & $4.67 \mathrm{aA}$ \\
\hline $\mathrm{CV} \%$ & & \\
\hline
\end{tabular}

Means followed by the same letters, lowercase and uppercase on the columns in the rows do not differ significantly according to Duncan's test at $5 \%$ probability.

${ }^{1 /}$ Remarks transformed into $\sqrt{\mathrm{x}}+1$. 
Apparently, it is possible to obtain a large number of shoots per explant by using SIT and increasing concentrations of 6-BA, bearing in mind that the trend of this variable is linear (Figure 2). However, the 6-BA concentration of the culture medium for shoot multiplication is related to the endogenous cytokinin concentrations of the explant. According to Moncaleán et al. (2003), endogenous cytokinin interacts with 6-BA of the culture medium and influences the proliferation of meristems. However, this depends on the culture medium, transport efficiency, and 6-BA metabolism.

Figure 2. Effects of different 6-BA concentrations on the number of shoots per explant during the multiplication phase of Agapanthus umbellatus var. minor in the semisolidified medium and liquid medium in the temporary immersion system.

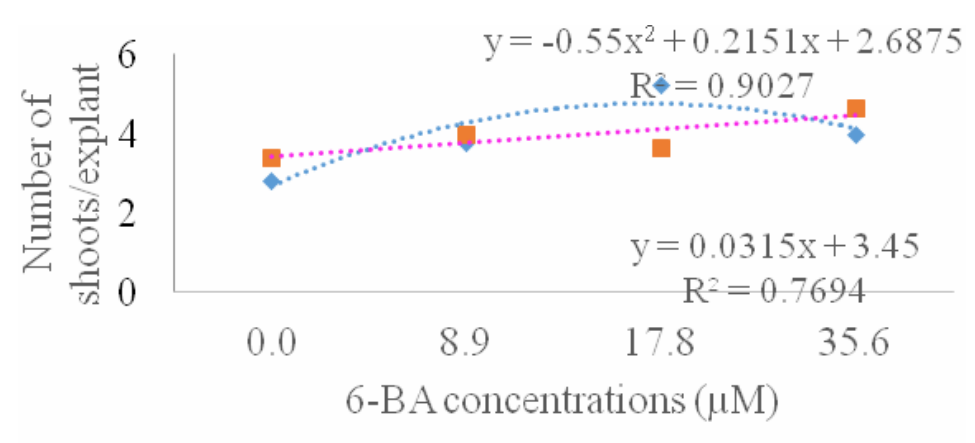

While the plants multiplied in the SM at high 6-BA concentrations, they showed a quadratic behavior (Figure 2), resulting in a drastic decrease in the number of shoots. Probably, this result is attributable to biochemical processes such as 6-BA absorption, distribution, and metabolism (MONCALEÁN et al., 1999). The presence of gelling agents in the culture medium can be a factor that influenced the conditions of the culture medium. According to George (1996) and Feito et al. (2001), agar hinders the spread of plant growth regulators and reduces the concentration of the regulators in the target areas of the shoots, resulting in lower middle-gradient explants. This can be the reason for the lower velocity of absorption of 6-BA and can ease inactivation of growth regulator or comparnentation in a more efficient way.
Although the main purpose of the multiplication phase is to produce as many seedlings in vitro as possible, the quality of seedling development should also be considered when determining the optimal 6-BA concentration. This is because small seedlings are not desirable in the multiplication process, since they require a stretching phase before the rooting phase to prevent any high losses in the acclimatization phase.

We analyzed the shoot height and number of leaves per shoot (Table 2), number of roots (Table 3), and fresh and dry mass (Table 4) and observed no interactions between the multiplication systems and 6-BA concentrations. The shoot height and number of leaves per explant were affected only by 6-BA concentrations (Table 2). Although the absence of 6-BA resulted in a lower number of shoots (Table 1), shoot height and number of leaves were superior at these concentrations (Table 2). 
Fogaça, A. L.; Pedrotti, E. L.; Alves, A. C.

Table 2. Shoot height and number of leaves per explant of Agapanthus umbellatus var. minor obtained after 60 days of culture in the semisolidified medium (SM), temporary immersion (SIT), and four concentrations of 6-BA.

\begin{tabular}{ccccccc}
\hline \multirow{2}{*}{$\begin{array}{c}\text { 6-BA concen- } \\
\text { tration }(\mu \mathrm{M})\end{array}$} & \multicolumn{5}{c}{ Shoot height $(\mathrm{cm})$} & \multicolumn{3}{c}{ Number of leaves $^{1}$} \\
\cline { 2 - 6 } & SM & SIT & Media & SM & SIT & Media \\
\hline 0 & 4.00 & 4.10 & $4.05 \mathrm{a}$ & 5.96 & 5.88 & $5.92 \mathrm{a}$ \\
8.9 & 2.72 & 3.27 & $2.99 \mathrm{~b}$ & 5.14 & 5.70 & $5.42 \mathrm{ab}$ \\
17.8 & 2.50 & 3.02 & $2.76 \mathrm{~b}$ & 4.93 & 5.22 & $5.07 \mathrm{bc}$ \\
35.6 & 2.74 & 2.28 & $2.71 \mathrm{~b}$ & 4.68 & 4.49 & $4.59 \mathrm{c}$ \\
\hline Average & $2.99 \mathrm{~A}$ & $3.17 \mathrm{~A}$ & & $5.17 \mathrm{~A}$ & $5.31 \mathrm{~A}$ & \\
\hline CV \% & & 12.43 & & 4.84 & \\
\hline
\end{tabular}

Means followed by the same letter, lowercase and uppercase on the columns in the rows do not differ significantly according to Duncan's test at $5 \%$ probability.

${ }^{1 /}$ Remarks transformed into $\sqrt{\mathrm{x}}+1$.

Table 3. Number of roots per shoots of Agapanthus umbellatus var. minor obtained after 60 days of culture in semisolidified medium, temporary immersion and in four concentrations of 6-BA.

\begin{tabular}{cccc}
\hline \multirow{2}{*}{$\begin{array}{c}\text { 6-BA concentration } \\
(\mu \mathrm{M})\end{array}$} & \multicolumn{2}{c}{ Multiplication system } & \multicolumn{2}{c}{ Media } \\
\cline { 2 - 4 } & Semisolidified medium $^{1}$ & Temporary immersion $^{1}$ & $3.28 \mathrm{a}$ \\
8.9 & 2.39 & 4.27 & $1.12 \mathrm{~b}$ \\
17.8 & 0.00 & 2.67 & $1.00 \mathrm{~b}$ \\
35.6 & 0.00 & 2.35 & $0.52 \mathrm{~b}$ \\
\hline Average & 0.00 & 1.16 & \\
\hline CV \% & $0.46 \mathrm{~B}$ & $2.53 \mathrm{~A}$ \\
\hline
\end{tabular}

Means followed by the same letter, lowercase and uppercase on the columns in the rows do not differ significantly according to Duncan's test at $5 \%$ probability.

${ }^{1 /}$ Remarks transformed into $\sqrt{\mathrm{x}}+1$.

With respect to the multiplication systems used, the shoots showed an equal growth rate in both systems because there were no differences with respect to shoot height and number of leaves. Lemos et al. (2001) obtained similar results for the number of leaves per explant during Musa sp. multiplication. They observed no significant differences between SM and SIT. However, previous studies on other species such as sugarcane (LORENZO et al., 1998), pineapple (ESCALONA et al., 1999), and orchid (SCHEIDT et al., 2009) showed that the SIT not only stimulated the formation of new shoots but also the length of the shoots, and these new shoots grew at a higher speed when SIT rather than SM was used. Thus, the growth of seedlings varied among species when different systems of propagation were used.
With respect to the number of roots in vitro (Table 3 ), we observed great efficiency in SIT in relation to SM. However, the shoots obtained via SM presented roots in MS medium without 6-BA (2.39 roots per shoot), and SIT promoted the formation of roots at all concentrations. These results are consistent with those obtained by Lemos et al. (2001), who reported higher efficiency of SIT during Musa sp. multiplication resulted in the higher production of roots.

In general, exogenous cytokinins inhibit root development; however, at low concentrations, they can have a promoter effect (ASSIS; TEIXEIRA, 1998), which was observed in the present study: a higher number of shoots were observed in SIT at lower 6-BA concentrations. 
Table 4. Fresh and dry mass ( $\mathrm{g}$ ) of shoots of Agapanthus umbellatus var. minor obtained after 60 days of culture in the semisolidified medium (SM), temporary immersion (SIT), and four concentrations of 6-BA.

\begin{tabular}{|c|c|c|c|c|c|c|}
\hline \multirow{3}{*}{$\begin{array}{l}\text { 6-BA concen- } \\
\text { tration }(\mu \mathrm{M})\end{array}$} & \multicolumn{3}{|c|}{ Fresh mass $(\mathrm{g})$} & \multicolumn{3}{|c|}{ Dry mass (g) } \\
\hline & \multicolumn{6}{|c|}{ Multiplication system } \\
\hline & SM & SIT & Media & SM & SIT & Media \\
\hline 0 & 0.4514 & 0.4987 & $0.4750 \mathrm{a}$ & 0.040 & 0.053 & $0.046 \mathrm{a}$ \\
\hline 8.9 & 0.5165 & 0.5799 & $0.5482 \mathrm{a}$ & 0.044 & 0.063 & $0.053 \mathrm{a}$ \\
\hline 17.8 & 0.5224 & 0.5812 & $0.5518 \mathrm{a}$ & 0.047 & 0.061 & $0.054 \mathrm{a}$ \\
\hline 35.6 & 0.5611 & 0.4775 & $0.5193 \mathrm{a}$ & 0.045 & 0.050 & $0.047 \mathrm{a}$ \\
\hline Average & $0.5128 \mathrm{~A}$ & $0.5343 \mathrm{~A}$ & & $0.0441 \mathrm{~B}$ & $0.0572 \mathrm{~A}$ & \\
\hline $\mathrm{CV} \%$ & & 24.00 & & & 24.00 & \\
\hline
\end{tabular}

Means followed by the same letter, lowercase and uppercase on the columns in the rows do not differ significantly according to Duncan's test at 5\% probability.

The renewal of the atmosphere in the culture flasks was another factor that probably influenced the higher root formation in SIT (Table 3). The atmospheric composition may have been influenced by the injection of air during the transfer of the medium, and it may have eliminated harmful compounds produced during plant metabolism. This system also had a great influence on induction and root growth (LUCCHESINI; SODI, 2004). According to these researchers, Phillyrea latifolia L. seedlings that multiplied in flasks after the renewal of the atmosphere showed a significant increase in the number, length, and dry weight of the roots.

However, the fresh weight showed no significant difference with respect to the 6-BA concentrations and the systems used for multiplication. It was observed that SIT caused a higher increase in shoot volume. This was confirmed by the production of dry matter (Table 4). This result is consistent with the findings of Scheidt et al. (2009), who reported a significant increase in fresh weight after using the immersion bioreactor. This increased production is probably due to greater contact of the explants with the liquid medium, which provided a greater area of absorption and hence better utilization of the culture medium. However, in the SM system, the contact area of the plant with the environment was limited to its base (LEMOS et al., 2001; RODRIGUES et al., 2006).
To briefly summarize, use of the SM system resulted in higher formation of new shoots at a lower concentration of 6-BA $(17.8 \mu \mathrm{M})$ when compared with SIT $(35.6 \mu \mathrm{M})$. This demonstrates that, despite the fact that this concentration stood out in comparison with other concentrations, this important parameter of growth aimed at a high rate of multiplication for seedlings on a large scale, and the increase in the concentration of 6-BA would not increase the amount of sprouting in this system.

The determination of optimal concentration of 6-BA for the multiplication phase of Agapanthus in both systems used multiplication, besides the number of shoots formed and in vitro development of them. We recommend $17.8 \mu \mathrm{M}$ 6-BA for the SM system and $8.9 \mu \mathrm{M}$ 6-BA for SIT. These concentrations promote the development of a large number of new shoots, and they result in a greater increase in seedling development, which could later influence the acclimatization phase.

The data obtained in this study demonstrated that the two systems used were efficient during the multiplication phase of Agapanthus umbellatus var. minor. However, SIT was better than the SM system because of the quality and uniformity of the aerial parts produced. Moreover, simple construction and low cost of the bioreactors characterized SIT as an alternative for large-scale production of Agapanthus umbellatus var. minor. 


\section{Conclusion}

In this study, the two in vitro systems used were efficient for the multiplication phase of Agapanthus umbellatus var. minor. However, temporary immersion could be recommended in view of its reuse in the process of multiplication and rooting. Among the 6-BA concentrations used, we recommend $17.8 \mu \mathrm{M}$ 6-BA for SM and $8.9 \mu \mathrm{M}$ 6-BA for SIT.

\section{References}

ALVARD, D.; COÔTE, F.; TEISSON, C. Comparison of methods of liquid medium culture for bananas micropropagation. Effects of temporary immersion of explants. Plant Cell Tissue and Organ Culture, Netherlands, v. 32, n. 1, p. 55-60, 1993.

ASSIS, T. F.; TEIXEIRA, S. L. Enraizamento de plantas lenhosas. In: TORRES, A. C.; CALDAS, L. S.; BUSO, J. A. (Ed.). Cultura de tecidos e transformação genética de plantas. Brasília: EMBRAPA-SPI/EMBRAPA-CNPH, 1998. p. 261-296.

BASKARAN, P.; STADEN, J. V. Rapid in vitro micropropagation of Agapanthus praecox. South African Journal of Botany, Nigéria, v. 86, n. 1 p. 46-50, 2013.

CALDAS, L. S.; HARIDASAN, P.; FERREIRA, M. E. Meios nutritivos. In: TORRES, A. C.; CALDAS, L. S.; BUSO, J. A. (Ed.). Cultura de tecidos e transformação genética de plantas. Brasília: EMBRAPA-SPI/ EMBRAPA-CNPH, 1998. p. 87-132.

ESCALONA, M.; LORENZO, J. C.; GONZÁLEZ, B.; DAQUINTA, M.; GONZÁLEZ, J. L.; DESJARDINS, Y.; BORROTO, C. G. Pineapple (Ananas comosus L. Merr) micropropagation in temporary immersion systems. Plant Cell Reports, Berlin, v. 18, n. 9, p. 743-748, 1999.

ETIENNE, H.; BERTHOULY, M. Temporary immersion systems in plant micropropagation. Plant Cell Tissue and Organ Culture, Netherlands, v. 69, n. 3, p. 215-231, 2002.

EXTERCKOKER, R.; PEDROTTI, E. L. Micropropagação de Agapanthus umbellatus var. minor. In: CONGRESSO BRASILEIRO DE FLORICULTURA, 13., 2001, São Paulo. Resumos... São Paulo: Editora, $2001.250 \mathrm{p}$.

FEITO, I.; GON'ZLEZ, A.; CENTENO, M. L.; FERNÁNDEZ, B.; RODRIGUEZ, A. Transport and distribution of benzyladenine in Actinidia deliciosa explants cultures in liquid and solid media. Plant
Physiology Biochemistry, Paris, v. 39, n. 10, p. 909-916, 2001.

FOGAÇA, L. A.; DORTZBACH, D.; ALVES, A. C.; PEDROTTI, E. L. Características morfofisiológicas de brotos micropropagados de agapantho sob diferentes intensidades luminosas e concentrações de sacarose. Scientia Agraria, Curitiba, v. 8, n. 4, p. 371-378, 2007.

GEORGE, E. F. Plant propagation by tissue culture. In Practice. London: Exergetics, 1996. v. 2, 1361 p.

LEMOS, E. E. P.; FERREIRA, M. S.; ALENCAR, L. M. C.de; OLIVEIRA, J. G. L.; MAGALHÃES, V.S. Micropropagação de clones de banana cv. terra em biorreator de imersão temporária. Revista Brasileira de Fruticultura, Jaboticabal, v. 23, n. 3, p. 482-487, 2001.

LORENZI, H. Plantas para jardim no Brasil: herbáceas, arbustivas e trepadeiras. 2. ed. Nova Odessa: Instituto Plantarum, 2015. 1120 p.

LORENZO, J. C.; GONZÁLEZ, B. L.; ESCALONA, $M$. Sugarcane shoot formation in an improved temporary immersion system. Plant Cell Tissue and Organ Culture, Netherlands, v. 54, n. 3, p. 197-200, 1998.

LUCCHESINI, M.; SODI, A. M. Influence of medium composition and vessel ventilation on in vitro propagation of Phillyrea latifolia L. Scientia Horticulture, Amsterdam, v. 100, n. 1-4, p. 117-125, 2004.

MONCALEÁN, P.; CANAL, M. J.; FEITO, A.; RODRIGUEZ, A.; FERNANDEZ, B. Cytokinins and mineral nutrition in Actinidia deliciosa shoots cultured in vitro. Journal of Plant Physiology, Toronto, v. 155, n. 4-5, p. 606-612, 1999.

MONCALEÁN, P.; RODRIGUEZ, A.; FERNADEZ, B. Effect of different benzyladenine time pulses on the endogenous levels of cytokinins, indole-3-acetic acid and abscisic acid in micropropagated explants of Actinidia deliciosa. Plant Physiology and Biochemistry, Paris, v. 41, n. 2, p. 149-155, 2003.

MURASHIGE, T.; SKOOG, F. A revised medium for rapid growth and bioassay with tobacco tissue cultures. Physiologia Plantarum, Copenhagem, v. 15, n. 3, p. 473497, 1962.

NASCIMENTO, M. M.; FERREIRA, M. A. C.; MALOSSO, M. G. Produção de mudas de carobina (Jacaranda decurrens Cham.) em sistema de imersão temporária com biorreatores do tipo R.I.T.A. Revista Brasileira de Plantas Medicinai, Campinas, v. 14, n. 2, p. 414-417, 2012.

RODRIGUES, P. H. V.; TEIXEIRA, F. M.; LIMA, A. M. L. P.; AMBROSANO, G. M. B. Propagação de 
mudas de helicônia em biorreator de imersão temporária. Bragantia, Campinas, v. 65, n. 1, p. 29-35, 2006.

SCHEIDT, G. N.; SILVA, A. L. L. da; DRONK, A. G.; BIASI, L. A.; ARAKAKI, A. H.; SOCCOL, C. R. Multiplicação in vitro de Oncidium leucochilum (Orchidaceae) em diferentes sistemas de cultivo. Biociências, Porto Alegre, v. 17, n. 1, p. 82-85, 2009.

SILVA, A. B.; PASQUAL, M.; TEIXEIRA, J. B.; ARAUJO, A. G. da. Métodos de micropropagação de abacaxizeiro. Pesquisa Agropecuária Brasileira, Brasília, v. 42, n. 9, p. 1257-1260, 2007.

SNOEIJER, W. Agapanthus: a revision of the genus. Portland: Timber Press, 2004. 372 p.

SUZUKI, S.; OOTA, M.; NAKANO, M. Embryogenic callus induction from leaf explants of the Liliaceous ornamental plant, Agapanthus praecox ssp. orientalis (Leighton) Leighton: Histological study and response to selective agents. Scientia Horticulture, Amsterdam, v. 95, n. 1-2, p. 123-132, 2002.
TEISSON, C.; ALVARD, D. A new concept of plant in vitro cultivation liquid medium: temporary immersion. In: INTERNATIONAL CONGRESS OF PLANT TISSUE AND CELL CULTURE, 7., 1994, Florença. Proceedings... Florença: ICPTCC, 1994. p. 54.

VILLA, F.; PASQUAL, M.; SILVA, E.F. Micropropagação de híbridos de orquídea em meio knudson com adição de vitaminas do meio ms, benzilaminopurina e carvão ativado. Semina: Ciências Agrárias, Londrina, v. 35, n. 2, p. 683-694, 2014.

WANG, Y.; FAN, X.; WANG, W.; ZHANG, D.; SHEN, $\mathrm{X}$. Regeneration of Agapanthus praecox ssp orientalis Big Blue via somatic embryogenesis. Propagation of Ornamental Plants, Sofia, v. 12, n. 3, p. 148-154, 2012.

ZONTA, E. P.; MACHADO, A. A. Sistema de análise estatística para microcomputadores - SANEST. Ilha Solteira: UNESP, 1984. 109 p. 
